\title{
Polyorchidism - An Incidental Finding During Orchidopexy: A Case Report and Review of the Literature
}

\author{
Ferid Ousman Mummed (iD' \\ Abdurahman Seid Endris ${ }^{2}$ \\ Maru Gama Erge iD ${ }^{2}$ \\ 'Urology Unit, Department of Surgery, \\ St. Paul's Hospital Millennium Medical \\ College, Addis Ababa, Ethiopia; ${ }^{2}$ Pediatric \\ Surgery Unit, Department of Surgery, \\ St. Paul's Hospital Millennium Medical \\ College, Addis Ababa, Ethiopia
}

\begin{abstract}
Polyorchidism is an extremely rare congenital anomaly, defined as the presence of one or more extra testicles. About 200 cases have been reported in the medical literature. Triorchidism is the commonest one among all supernumerary testes. We present a rare case of incidentally detected polyorchidism during orchidopexy for ipsilateral undescended testis in a 7-year-old boy. The surgeon should be aware of this condition during groin exploration. The reproductive potential, location of the supernumerary testes, the coexistence of other disorders, and suspicion of the malignancy should be taken into account when choosing conservative management or surgery.
\end{abstract}

Keywords: congenital anomaly, polyorchidism, triorchidism, supernumerary testis, undescended testis, orchidopexy

\section{Introduction}

Polyorchidism is a very rare congenital testicular anomaly characterized by the presence of an extra testis in addition to the two independent native testes. Thus far, there have been more than 200 cases reported in the medical literature, since the first histologically confirmed case in 1880 . The supernumerary testis can be either intra-scrotal or extra-scrotal in location. The exact etiology is unclear. Polyorchidism is more common on the left side. Triorchidism is the commonest one among all supernumerary testes. ${ }^{1,2}$

Polyorchidism is usually discovered incidentally on imaging or during surgical exploration for other inguinoscrotal pathologies. The most common associated anomalies are undescended testis (40\%), inguinal hernia (30\%), testicular torsion $(13 \%)$, hydrocele $(9 \%)$ and hypospadias $(1 \%)$. The estimated risk of malignancy is around $6 \%$ and cryptorchidism appears to be the most important risk factor for malignancy. $^{3}$

The management of polyorchidism remains debatable, but it depends on patientrelated factors, such as the location of the testis, the reproductive potential, the size of the testis, and the age of the patient. The orthotopic supernumerary testis can be managed conservatively with clinical surveillance. However, for polyorchidism with extra-scrotal testis or the presence of associated complications such as testicular atrophy, torsion, or malignancy, surgical exploration is recommended. ${ }^{1-3}$ Here we present a case of incidentally detected polyorchidism during orchidopexy for the left undescended testis in 7-year-old boy. 


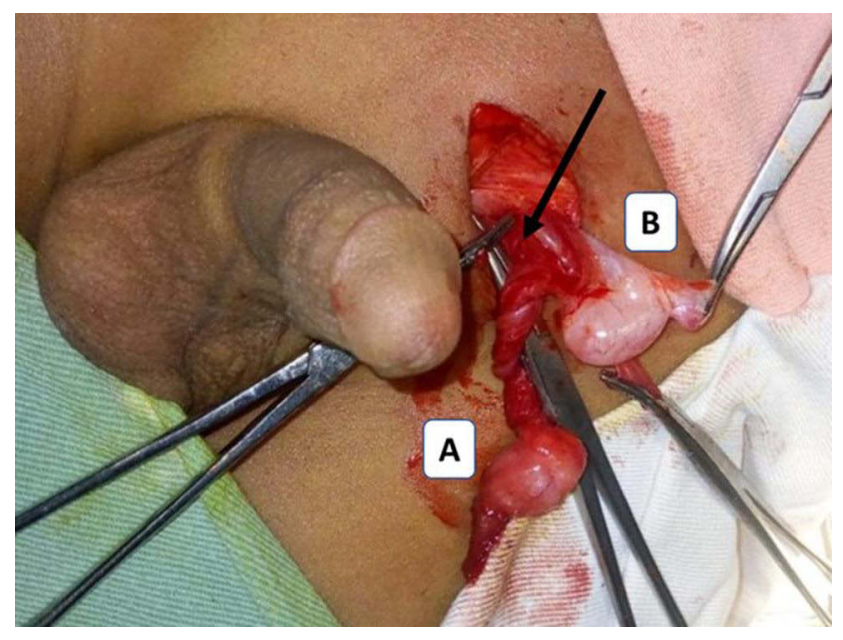

Figure I Intraoperative picture; left polyorchidism with a separate epididymis and common vas deferens. Caudal testis (A), cranial testis (B), common vas (black arrow).

\section{Case Presentation}

A 7-year-old boy presented to our clinic with the complaint of absent left testis since birth. He does not have any comorbidities. There was no family history of testicular anomalies. Physical examination revealed a normal testis in the right hemi-scrotum and a normal circumcised penis. The left hemi-scrotum was empty with a palpable testis in the left inguinal area. Clinical diagnosis of leftsided cryptorchidism was made. Since the testis was palpable, ultrasound or other imaging was not done and the patient was directly scheduled for elective orchidopexy after written consent was taken from his parents. The patient was explored through the left inguinal incision, which revealed two non-atrophic left testes located in the inguinal region with a separate epididymis and common vas deferens [Figure 1]. Considering the age of the patient, the testicular size, location, and his future fertility, we decided to preserve the testes. Standard inguinal orchidopexy techniques for palpable inguinal undescended testis were followed. Both testes were brought down and delivered through a separate left hemi-scrotal incision, followed by placement of the testes in a separate subdartos pouch. The patient was discharged on the next day and was doing well during the subsequent follow-up visits. The parents were counselled about the potential risk of testicular cancer post-orchidopexy and were strongly advised for routine surveillance, including the boy's monthly testicular self-examination (TSE) and ultrasound screening every 1-2 years from puberty onward.

\section{Discussion}

Polyorchidism is an extremely rare congenital genitourinary anomaly, defined as the presence of three or more testicles. About 200 cases have been reported in the medical literature. Most patients are reported to be in their early adulthood, with approximately $50 \%$ of cases reported between 15 and 25 years of age.,

Although the exact etiology of polyorchidism is not known, the proposed mechanism is considered to be a longitudinal or transverse division of the genital ridge, possibly due to the development of peritoneal bands during early embryogenesis. Depending upon the level of the division and the segmentation plane, the supernumerary testis may or may not remain in communication with the vas deferens and epididymis. ${ }^{2,3,5}$

Different classification systems have been reported in the literature. Leung described the anatomical variations on a possible embryological basis. Type 1: the supernumerary testis that lacks an epididymis or vas. Type 2: the supernumerary testis draining into the epididymis of the usual testis and sharing a common vas deferens. Type 3 : the supernumerary testis has its epididymis and drains into common vas deferens. Type 4: Complete duplication of testis, epididymis, and vas deferens. Type 2 is considered to be the most common and together with type 3, they comprise $90 \%$ of polyorchidism..$^{2-7}$ In our case, the patient had type 3 polyorchidism with completely separate epididymis but shares the vas deferens.

Triorchidism is the most common type of polyorchidism, and it has a left-sided predominance (66\%) which was also the case in our patient. The most common location of the polyorchid testis is within the scrotum $(66 \%)$, followed by inguinal (23\%) and abdominal (9\%). Bilateral supernumerary testicles have also been reported. The commonest associated anomalies are undescended testis (40\%) inguinal hernia (30\%), testicular torsion (15\%), hydrocele $(9 \%)$, and malignancy $(6 \%) .{ }^{1-3}$ Our case had triorchidism presenting as unilateral double undescended testes in the inguinal region.

The majority of the patients are asymptomatic and are incidentally detected during the evaluation or surgical management of other associated inguinoscrotal pathologies such as undescended testis, testicular torsion, inguinal hernia, hydrocele, and others. ${ }^{2,3,7}$ In our case, the polyorchidism was detected incidentally during exploration for left undescended testis.

The management of polyorchidism is still highly debated in the literature. Several authors recommend surgical 
Table I Summary of the Literature Review of Case Reports and Case Series

\begin{tabular}{|c|c|c|c|c|c|c|}
\hline Authors & Year & Title & Journal & Age & Diagnosis & Management \\
\hline $\begin{array}{l}\text { Balawender } \\
\text { et al }\end{array}$ & 2021 & $\begin{array}{l}\text { Management of Incidental Finding of Triorchidism Diagnosed } \\
\text { During Routine Hernia Repair }\end{array}$ & $\begin{array}{l}\text { Research and } \\
\text { Report in } \\
\text { Urology }\end{array}$ & $21 \mathrm{yr}$ & Incidental & Orchidectomy \\
\hline $\begin{array}{l}\text { Tigabie } \\
\text { et } \mathrm{al}^{2}\end{array}$ & 2020 & $\begin{array}{l}\text { Triorchidism: Unilateral double atrophic undescended testis } \\
\text { in Tertiary Specialized Hospital, Ethiopia }\end{array}$ & $\begin{array}{l}\text { Journal of } \\
\text { Pediatric Surgery } \\
\text { Case Reports }\end{array}$ & $4 y \mathrm{r}$ & Incidental & Orchidectomy \\
\hline Assefa et $\mathrm{al}^{3}$ & 2021 & Triorchidism, a Rare Genitourinary Anomaly: A Case Series & $\begin{array}{l}\text { Research and } \\
\text { reports in urology }\end{array}$ & $\begin{array}{l}5 \mathrm{yr} \\
\text { and } \\
12 \mathrm{yr}\end{array}$ & Incidental & $\begin{array}{l}\text { Orchidopexy } \\
\text { (Ist case) } \\
\text { Orchidectomy } \\
\text { (2nd case) }\end{array}$ \\
\hline $\begin{array}{l}\text { Chowdhary } \\
\text { et al }\end{array}$ & 2016 & Case report of a rare variant of polyorchidism & $\begin{array}{l}\text { Journal of } \\
\text { Pediatric Surgery } \\
\text { Case Reports }\end{array}$ & $6 \mathrm{~m}$ & Incidental & Orchidopexy \\
\hline $\begin{array}{l}\text { Sönmez } \\
\text { et } \mathrm{al}^{5}\end{array}$ & 2012 & Polyorchidism: A Case Report and Review of the Literature & Andrology & $37 y r$ & $\begin{array}{l}\text { Clinical (P. } \\
\text { E and } \\
\text { USG) }\end{array}$ & USG follow-up \\
\hline $\begin{array}{l}\text { Wilcox } \\
\text { et al }\end{array}$ & 2013 & $\begin{array}{l}\text { Polyorchidism in association with an undescended testis and } \\
\text { testicular atrophy: Report of a unique case and review of the } \\
\text { literature }\end{array}$ & $\begin{array}{l}\text { Journal of } \\
\text { Pediatric Surgery } \\
\text { Case Reports }\end{array}$ & $14 \mathrm{yr}$ & Incidental & Orchidectomy \\
\hline Kumar et al ${ }^{7}$ & 2008 & Supernumerary testis: a case report and review of literature & $\begin{array}{l}\text { Journal of } \\
\text { pediatric surgery }\end{array}$ & $3 y r$ & Incidental & Orchidopexy \\
\hline
\end{tabular}

exploration for patients with non-scrotal supernumerary testes. The other debatable issue is to either do orchidopexy or orchidectomy for the supernumerary testis. In general, in a young patient of reproductive age with grossly nonatrophic testes and clinically no concern of malignancy, orchidopexy is recommended if feasible, followed by routine clinical surveillance. However, in the presence of any concomitant disorder, atrophy, and suspected testicular malignancy, surgical exploration with biopsy is necessary. ${ }^{1-3,6,7}$

In our patient, the supernumerary testes were located within the inguinal area and appeared grossly nonatrophic; given the low risk of malignancy and its potential to contribute to reproduction, we fixed both testes in the hemi-scrotum and counseled the parents on the remote risk of malignancy and the need for long-term surveillance.

Table 1 shows seven comparable articles.

\section{Conclusion}

Polyorchidism is a rare urogenital anomaly. Polyorchidism should be kept in mind during groin exploration. Although the management is controversial, exploration is warranted for mal-descended supernumerary testes and/or the presence of complications like atrophy, testicular torsion, or suspected malignancy.

\section{Data Sharing Statement}

All the generated data are included in this article.

\section{Ethics Approval and Consent to Participate}

No institutional review board approval was required.

\section{Consent for Publication}

Written informed consent was obtained from the parents for the publication of this case report and accompanying images. A copy of the written consent is available for review.

\section{Author Contributions}

All authors made a significant contribution to the work reported, whether that is in the conception, study design, execution, acquisition of data, analysis and interpretation, or in all these areas; took part in drafting, revising or critically reviewing the article; gave final approval of the 
version to be published; have agreed on the journal to which the article has been submitted; and agree to be accountable for all aspects of the work.

\section{Funding}

The authors received no funding for writing of this article.

\section{Disclosure}

The authors declare that they have no conflicts of interest in this work.

\section{References}

1. Balawender K, Wiatr T, Wawrzyniak A, Orkisz S. Management of incidental finding of triorchidism diagnosed during routine hernia repair. Res Rep Urol. 2021;13:127-131. doi:10.2147/RRU.S291621
2. Tigabie W, Dejenie B. Triorchidism: unilateral double atrophic undescended testis in Tertiary Specialized Hospital, Ethiopia. $J$ Pediatr Surg Case Rep. 2020;61:101633. doi:10.1016/j. epsc.2020.101633

3. Assefa HG, Erge MG, Gebreselassie HA. Triorchidism, a rare genitourinary anomaly: a case series. Res Rep Urol. 2021;13:549-552. doi:10.2147/RRU.S323558

4. Chowdhary S. Case report of a rare variant of polyorchidism. $J$ Pediatr Surg Case Rep. 2016;5:30-31. doi:10.1016/j. epsc.2015.12.007

5. Sönmez N, Kilinc M, Arısan S, Calıskan KC. Polyorchidism: a case report and review of the literature. Andrology. 2012;1(102):2167.

6. Wilcox CB, D'Cruz R, Holland AJA. Polyorchism in association with an undescended testis and testicular atrophy: report of a unique case and review of the literature. J Pediatr Surg Case Rep. 2013;1(1):e7-e9. doi:10.1016/j.epsc.2012.12.001

7. Kumar B, Sharma C, Sinha DD. Supernumerary testis: a case report and review of literature. J Pediatr Surg. 2008;43(6):E9-e10.

\section{Publish your work in this journal}

Research and Reports in Urology is an international, peer-reviewed, open access journal publishing original research, reports, editorials, reviews and commentaries on all aspects of adult and pediatric urology in the clinic and laboratory including the following topics: Pathology, pathophysiology of urological disease; Investigation and treatment of urological disease; Pharmacology of drugs used for the treatment of urological disease. The manuscript management system is completely online and includes a very quick and fair peer-review system, which is all easy to use. Visit http://www.dovepress.com/ testimonials.php to read real quotes from published authors. 